\title{
Understanding changes in teacher beliefs and identity formation: A case study of three novice teachers in Hong Kong
}

\section{Jing Huang, Yi Wang \& Feng Teng}

To cite this article: Jing Huang, Yi Wang \& Feng Teng (2019): Understanding changes in teacher beliefs and identity formation: A case study of three novice teachers in Hong Kong, Teaching Education, DOI: 10.1080/10476210.2019.1693535

To link to this article: https://doi.org/10.1080/10476210.2019.1693535

曲 Published online: 04 Dec 2019.

Submit your article to this journal $₫$

Q View related articles ¿

View Crossmark data $\complement$ 


\title{
Understanding changes in teacher beliefs and identity formation: A case study of three novice teachers in Hong Kong
}

\author{
Jing Huang $\mathbb{( D}^{a}$, Yi Wang $\mathbb{D}^{b}$ and Feng Teng $\mathbb{D D}^{a}$ \\ a'Department of Education Studies, Hong Kong Baptist University, Hong Kong, China; bWaikato Institute of \\ Technology, Hamilton, New Zealand; Shandong University of Technology, Zibo, China
}

\begin{abstract}
Novice teachers often undergo an identity shift from learner to teacher. Along this process, their instructional beliefs change considerably which in turn affect their teacher identity formation. Drawing on data collected mainly through interviews with three novice English teachers for more than one year, the present study examines their firstyear teaching experience in Hong Kong secondary schools, focusing on changes of their English teaching beliefs and the impact of these changes on their identity construction. Findings reveal that while the teachers' initial teaching beliefs were largely shaped in their prior school learning and learning-to-teach experience, these beliefs changed and were reshaped a great deal when encountering various contextual realities, and these changes further influenced their views on their teacher identity establishment, unfortunately in a more negative than positive direction. The study sheds light on the importance of institutional support in affording opportunities for novice teachers' workplace learning and professional development.
\end{abstract}

\section{ARTICLE HISTORY}

Received 3 March 2019

Accepted 27 October 2019

\section{KEYWORDS}

Novice teachers; teacher beliefs; teacher identity; teacher education

\section{Introduction}

Teachers' beliefs interact bi-directionally with their experience. In the case of novice teachers, their experience normally involves their learning at school, teacher education in the university when they learn how to teach, teaching practicum back to school again where they try out what they have learned, and first year teaching in schools where the mix of what they have learned and experienced 'touch down'. While teacher beliefs change over time in general, the changes involved in the learner-teacher transition are particularly massive, when they are said to be moving 'from one world to another' and facing the challenge of adapting to 'vastly different, novel environments that require skills and talents not fully developed prior to entry into their puzzling new world' (Saunders \& Ash, 2013, p. 490).

It is against this backdrop of learner-teacher transition that this study was carried out, with a primary focus on novice English teachers' evolving beliefs and teacher identity. Specifically, two research questions were addressed: (1) What changes occurred to the novice teachers' teaching beliefs in their first-year learner-teacher transitional period? (2) How did the changes in their teaching beliefs influence the formation of their teacher identity? 


\section{Teacher identity construction}

Teacher identity is multifaceted and dynamic and understanding teacher identity is central to language teaching and learning (Beauchamp \& Thomas, 2009; Varghese, Morgan, Johnston, \& Johnson, 2005). Identity is 'constructed within an active process of creation and recreation' (Trent, 2010, p. 153). This echoes Britzman's (2003, p. 31) view of learning to teach as 'the process of becoming' and of 'formation and transformation'. In other words, teacher learning can be conceptualised as 'identity learning' (Beijaard, 2019).

Teacher identity is developed through a struggle for voice (Britzman, 2003). Britzman (2003, 2009) identifies three dimensions of voice: biography, emotions and institutional structure. Biography refers to experiences of a person's life and schooling journey. Emotions concern the intimate, personal and internal aspects of teacher identity and how inconsistencies, uncertainties and what is often kept silent contribute to becoming a teacher. Institutional structures are forces legitimising and exerting control over subjectivities and practices within teaching. It is through the interaction and negotiation of these voices that teacher identity develops.

Orr's (2012) study of both in-service and pre-service trainee teachers in England provides an alternative angle to look at teacher identity construction. Orr suggests that learning to teach might become a process of 'learning to cope' (p. 56) with difficult circumstances of teaching (e.g. teaching long hours and fulfilling administrative duties) and lack of control over their classroom practice which prescribes criteria and conformity. In coping with these difficulties, isolation, due to little mentor support and restricted collaboration among colleagues, is 'a prominent feature' (p. 53). The tightly controlled school system demands conformity and constrains professional autonomy, which affects teachers' confidence and thus shapes their 'evolving self-identification as a teacher' (p. 59).

Trent (2017) studied five former English language teachers in Hong Kong regarding their experiences during the initial years of teaching and the reasons for their permanent departure from the teaching profession. Through presenting 'the harder to tell and to hear stories' ( $p$. 85), the study documents the ways in which these former teachers perceived the constraints and enablements to their professional identity construction within the context of their ultimate decision to exit the teaching profession. Results of the study problematise rigid divisions between different types of teachers and propose the need to establish 'identity spaces' (p. 103) that allow for the meshing of different teacher identities. Furthermore, Trent (2019) reports on a qualitative case study investigating the reasons why a group of graduates from an initial English language teacher education programme in Hong Kong chose not to enter the teaching profession. Findings of the study reveal how these former pre-service English language teachers struggled to construct, particularly during the teaching practicum, their preferred professional identities (i.e. teachers as 'kind and caring'); and how the denial of their agency to construct their preferred identities contributed to their decision not to pursue a teaching career. Both studies by Trent $(2017,2019)$ highlight the role of agency in identity formation and the need to foster agency of pre-service and in-service teachers by contesting dominant educational discourses that position all teachers in particular ways.

In line with the narrative work on teacher attrition in other contexts (e.g. Schaefer, 2013; Schaefer \& Clandinin, 2011, 2019; Schaefer, Downey, \& Clandinin, 2014), Harfitt (2015) inquired into teacher attrition and retention through the lens of two Hong Kong novice teachers' narrative accounts (i.e. their stories to live by). The study documents how 
their personal and professional landscapes 'bumped' and 'merged' (p. 33). The inquiry also demonstrates how 'it has been possible to see identity change as a framework for conceptualising the global phenomenon of teacher attrition' (p. 33). Findings of the study point to the necessity of allowing beginning teachers adequate time to develop as teachers rather than expecting them to cope with the work and tasks normally reserved for more experienced teachers (see also Orr, 2012).

\section{Teachers' epistemological beliefs}

Teachers' professional identity shapes and is shaped by their epistemological beliefs. Calderhead (1996) asserts that teachers' beliefs include teachers' pedagogical beliefs and those beliefs that are relevant to an individual's teaching. As a key element in teacher learning (Borg, 2011), beliefs are considered the clearest measure of teachers' professional growth (Kagan, 1992). Teacher education plays an important role in fostering the integration between beliefs and theory.

Pre-service teachers enter teacher education programmes with their own sets of preexisting epistemological beliefs, which mediate teacher learning (Hollingsworth, 1989; Holt-Reynolds, 1992). On one hand, such beliefs act as a filter 'limiting the ideas that teacher education students are able and willing to entertain' (Feiman-Nemser, 2001). On the other hand, beliefs guide teachers' justification and evaluation of knowledge (Kuhn \& Weinstock, 2002). Their personal epistemologies influence their teaching conceptions, approaches to learning (Chan, 2003), gains from observing exemplary teaching practices (Yadav \& Koehler, 2007), teaching goals and strategies (Kang, 2008), and teaching practices (Tsai, 2003).

Brownlee (2004) suggests that pre-service teachers with objectivist personal epistemologies are more likely to view teaching as a one-way interaction while those with relativist epistemologies tend to favour a constructivist approach to teaching. Hashweh (1996) found that teachers with constructivist epistemology tend to use more effective teaching strategies. They tend to view their students as competent, active, able to construct meaning on their own and worthy of respect (Brownlee, Edwards, Berthelsen, \& Boulton-Lewis, 2011). They are also more likely to nurture students with similar epistemologies compared with teachers holding a more absolutist epistemology (Brownlee et al., 2012). On the other hand, Cheng, Chan, Tang, and Cheng (2009) argue that preservice teachers with sophisticated epistemology do not necessarily employ more constructivist approaches in their teaching. Chai, Khine, and Teo (2006) suggest that this discrepancy between beliefs and actual teaching might occur for several reasons. First, pre-service teachers may want to adhere to a didactic approach since they are not ready to give up their authority. Second, these teachers may hold two sets of beliefs, one for their personal epistemology and another for teaching. Third, the school context may not encourage the implementation of active learning pedagogies (see also Kang, 2008). Roth and Weinstock (2013) went a step further by looking into a possible relationship between teachers' epistemological beliefs and autonomy-supportive teaching (AST). Their study discovered that 'AST mediated the link between teachers' epistemology and students' autonomous motivation' (p. 408). 


\section{The study}

\section{Research setting and participants}

The study was conducted in Hong Kong secondary schools with three novice English teachers. The selection of participants first adopted a convenience sampling approach (Merriam, 2009) - potential participants were considered among former students of the first author. Specifically, the students then were studying an ELT paper that the first author was teaching, and the paper fulfillment required a reflective journal writing portfolio (autobiography) on their English learning and teaching experience, which related closely to language teacher development. Meanwhile, the participant selection was purposeful (Merriam, 2009), and three criteria were established in this case: teaching full time in local secondary schools; being novice with no more than two years' teaching experience; willing to articulate and share their experience with the researchers. Based on both convenient and purposeful approaches, three teachers were chosen, namely Stella, Courtney, and Sally (pseudonyms).

The three participants worked in three different schools, which had different features and settings. Stella described her workplace as 'a traditional school with a strong focus on Christian origin' and teaching approaches as largely examination-oriented applying much mechanical drilling. Courtney's school was boys only - which seemed to require teachers' greater patience in lesson delivery and classroom management - its focus was cultivation of citizen qualities (e.g. responsibility and integrity). Sally's school was involved in the Direct Subsidy Scheme initiated by the Hong Kong SAR government since 1991, and the teaching approach was outcome-based, highlighting the learning product.

\section{Data collection and analysis}

This qualitative study employs a case study approach. A qualitative design allows individuals to 'construct reality in interaction with their social worlds' (Merriam, 2009, p. 22), which makes it possible for researchers to 'develop an in-depth exploration of a central phenomenon' (Creswell, 2012, p. 206). A case study approach, referred to as 'interpretation in context' (Merriam, 2009, p. 42), enables the researchers to capture the complexity of the participants' action, perception and interpretation. Such a design therefore suits the purpose of this investigation, which aims at understanding the complexity of novice teachers' learner-teacher transition and the degree of control they have over their initial year of teaching.

Interviews were the major means of data collection. Through interviewing our participants at different time points for more than one year, changes in their thoughts and beliefs over time were tracked, influence of belief changes on identity formation revealed, and contributing factors behind the changes explored. These, integrated together, uncovered the complex interaction and interrelation between teachers' beliefs, identities and contextual factors. Three to four semi-structured interviews were conducted with each participant over a year, each about one hour long. The working language for the interviews was English based on the participants' choice.

A total of ten interviews were conducted in three rounds in 2013/2014. The first round, held at the beginning of the school year in late August or early September 2013, explored the participants' experiences as EFL learners and their expectations towards their first job as a teacher. The second round (except for Sally) was carried out in January 2014, which aimed 
to obtain updates on the participants' teaching lives and to seek clarification on any unclear points mentioned in previous interviews. In Sally's case, this was the third interview because the second one was specially arranged in October 2013, when she was particularly eager to share her teaching life then. The final round took place towards the end of the academic year in July 2014. These interviews first invited the participants to self-evaluate their initial year performance and then probed into their future plans, particularly regarding their motivation to stay on with, or intention to quit, teaching.

Apart from interviews, data were also collected through other means, including school documents (e.g. Schemes of Work, timetables), and as mentioned above, personal communication with the participants and their English learning and teaching portfolios. The portfolio provided an autobiographical account of the English learning and learning-toteach experiences over time and across settings. These accounts served to confirm and supplement the interview data, and enabled the researchers to see a comprehensive picture of their EFL learning and learning-to-teach journey. To track the participants' changes of beliefs and identity formation for a longer time to construct fuller stories, data collection was extended until their third (2015/16) and fourth (2016/17) school year, through personal communications (e.g. email, WhatsApp, and telephone). These portfolios, together with the subsequent contacts, presented a fuller picture of each participant's experience of learning and learning to teach in the Hong Kong educational settings.

When revising this article, all three participants were invited to participate in the first author's new project, which was an extension of the previous project on which this paper was based. They were all interviewed in April 2019 and these interviews were built upon earlier interviews conducted in their first year of teaching. Although space only allows a selection of relevant interview findings, revisiting their development trajectories within the last few years helps us better understand their lived stories in their first-year teaching reported in this paper.

Data analysis adopted an 'inductive investigative strategy' (Merriam, 2009, p. 39). All the data obtained from the interviews and other sources were used to construct field and research texts, which were then sent to the participants to review and make additions, amendments, and/or clarifications (see Harfitt, 2015, p. 26). Data analysis and interpretation occurred along with data collection. Iterative reading, coding, and analysis of the data allowed themes to emerge, which were further organised with reference to the key constructs of the study. On such a basis, understanding was gradually developed regarding how the teacher participants constructed their professional identities. This aligned with Merriam's (2009) suggestion that qualitative researchers should analyse data through referring to the theory. In our case, in order to understand the teacher participants' identity construction, we drew upon aspects of teacher beliefs.

\section{Findings}

\section{Stella's story}

Born and raised in Hong Kong, Stella experienced a textbook-based rote learning approach in her initial years of English learning in primary school. She first tasted the fun of learning English when she was in Primary Five and Six when her English teacher included lots of activities in class. The good English foundation laid in senior primary enabled Stella to 
perform well in English in secondary school. She eventually opted for a double-degree in English and ELT in a local university. When this study was carried out, she was a first-year junior form (grade) English teacher at her alma mater. Starting off her career at her alma mater, Stella did not have a major problem adapting to the school environment. However, her shift of identity from a student to a teacher at that same school created anxiety in her. While most of her colleagues were friendly and helpful, Stella felt embarrassed in seeking help from them, most of whom used to be her teachers: 'I feel I have been their child' $\left(1^{\text {st }}\right.$ interview). While she aspired to cultivate an interest in English and proper attitudes in her students and to be their role model, she was not confident in teaching English prior to the start of the school year. 'I will try at least. If that doesn't work out, I may change my mind ... I want to see if my ability allows me to do that', Stella remarked ( $1^{\text {st }}$ interview).

Four months into her teaching, she experienced trouble coping with the teaching schedule, partly because of discipline problems during lessons, partly due to the many extra-curricular activities that she was in charge of, and partly due to the extra after-school tutorials she offered to her less capable students. She did not have adequate time to prepare for her lessons. As Stella remarked, ' ... as long as I can accomplish what is assigned in the Scheme of Work, it's already very good' ( $2^{\text {nd }}$ interview).

One thing that frustrated Stella was the poor learning attitude of some students, who 'are used to' and 'take for granted' teachers' spoon-feeding ( $2^{\text {nd }}$ interview). She had 'too much expectation' on students' learning attitude ( $2^{\text {nd }}$ interview). She also had high self-expectation, creating stress in herself: 'You don't know if you are doing well, if your students cannot understand you' ( $2^{\text {nd }}$ interview). Despite her sense of isolation and her colleagues being 'very willing to help', she was reluctant to share her difficulties with them, because she feared that would reveal her 'incompetency in front of very efficient colleagues' ( $3^{\text {rd }}$ interview).

Stella was not able to strike a good work-life balance. She recognised the need to take regular breaks from her work, but had to work after school and at home. On a typical school day, Stella worked in her school from 8 a.m. to 6 p.m. and continued with marking and lesson preparation in the evening at home. She was still worried about her students even when she was not occupied with her work, 'Sometimes I can't sleep because of that. It's a lot of pressure because I am a new teacher' ( $2^{\text {nd }}$ interview).

Towards the end of the school year, Stella wanted to seek another teaching post less faraway and demanding. However, she eventually gave up her job-searching and decided to stay in that school for another year. In a conversation with the first author in her third school year (2015/2016), Stella said, 'I was able to adapt better into the teaching environment from the second year. During the first year, it was indeed rather challenging to get hold of the curriculum'. She then explained, 'I was assigned two English classes only and the teaching materials for classes I taught in my first year could be used again ... and also four classes of Religious Studies'. She stressed the word 'only' and explained that as a Christian herself, she found it 'much easier to prepare for Religious Studies than core subjects such as English' (Fieldnotes, 28 March 2016). Altogether, Stella stayed on teaching in her alma mater for three years before moving to a direct subsidy school admitting 'better students' in her fourth year (2016/2017). The new school, in her views, is 'a better school', where 'teachers always work collaboratively to maximise learning', and where 'students wouldn't challenge my bottom line' (interview on 15 April 2019). The subsequent conversation and interview further demonstrate that overwhelming workload, student attitudes or discipline problems, and an absence 
of (aspiration for) collaboration made her first year teaching very stressful and thus prevented her from constructing a positive teacher identity.

\section{Sally's story}

Sally spent her initial years in mainland China before moving to Hong Kong at the age of nine. Due to limited exposure to English, her English level remained low in primary school years. She met a passionate English teacher in junior secondary school who offered her extra lessons during which she explained grammar rules to her patiently. She 'fell in love with English' (Portfolio/Autobiography) when she immersed herself in English in her secondary school through extensive reading and classroom activities. She took English literature in senior secondary and enjoyed the cultural immersion during literature lessons. When this study was carried out, Sally was a first-year teacher in a local secondary school.

Sally was quite optimistic towards her job, although she knew that her lack of teaching experience might present some challenges in handling parents and students' problems. She was assigned a mentor to help her settle in and she found her colleagues supportive. Sally believed that teachers are mentors and friends of students and she was willing to establish a friendly relationship with them based on mutual respect. Sally also believed that she was a facilitator of her students' learning: ' . . what we can teach in class is very limited, but what students can do after class is unlimited' ( ${ }^{\text {st }}$ interview). She attached great importance to building students' interest of using English for communication so that they could explore the language on their own outside of class.

Sally enjoyed the first two months of her teaching. She found herself in a small-class teaching environment, with no more than 20 students in a class. She had a good relationship with most of them and they treated her like their friend. However, Sally felt that she was too lenient to them, 'I think it takes time to sort out how to strike a balance between being a friend of them and at the same time being an authority' ( $2^{\text {nd }}$ interview).

Sally found lesson planning and implementation manageable since the Schemes of Work were well designed and clearly presented. Sally had ample time to complete her teaching and conducted class activities such as guessing games and group writing from time to time. Sally was involved in a number of school committees but her roles were assistive so her non-teaching workload was reasonable.

After a term, however, Sally realised that she lacked job satisfaction. Based on what she said in the third and fourth interviews, one obvious reason was that she became tired of travelling a long distance to school every day. Another reason was that she did not feel 'a sense of connection' with her fellow teachers, whom she described as 'mostly fresh graduates or teachers who have worked for just a few years'. As a novice teacher she imagined to 'collaborate with and learn from teachers from different backgrounds and of different ages' ( $3^{\text {rd }}$ interview).

What is worse, she came to realise that her efforts in improving teaching were not appreciated by her students and colleagues. She felt that she was not performing her teaching duties satisfactorily, especially regarding classroom management. She once remarked, 'students would take advantage of your kindness and they would take a step further to do whatever they want' ( $3^{\text {rd }}$ interview). She was annoyed when her students did not react positively to her teaching. Feeling isolated, she started questioning her ability as a teacher. 
To wrap up her first year of teaching, she has changed 'from a more positive and optimistic person to a more negative, pessimistic person' ( $4^{\text {th }}$ interview).

Realising she was not working in an atmosphere that she desired, her belief in teaching began to waver. She made up her mind to quit teaching altogether towards the end of the school year, but subsequently found an attractive teaching post in a school which had a religious background similar to her own and was much closer to where she lived. After careful consideration, Sally decided to give herself a second try staying as a teacher in another school (her second school). She eventually stayed in the second school for two years after her contract ended in August 2016. In an unplanned conversation in September 2016, her descriptions of her second school were full of expressions such as 'I really enjoyed teaching in the school', 'my students could feel how much efforts I have put in teaching them', 'a good teacher-student relationship' and 'a sense of achievement', and so on.

Leaving her second school, she enrolled in a part-time two-year MEd programme (2016-2018) to pursue her 'own professional development' and worked as a part-time substitute teacher in several schools. After graduation from the MEd programme, she began to teach full-time again in another school, her third school, but this experience became a 'disaster'. In the interview in April 2019, her descriptions of her third-school experience were full of negative comments such as 'real isolation', 'no collaboration', 'no sharing among colleagues allowed', 'unreasonable and demanding panel head and principal', 'damaging classroom revisits or rechecking of student assignments', 'offended, untrusted, and unrespected', and 'no support at all from the school'. Consequently, this 'really damaging experience' resulted in 'frustration', 'stress', 'depression' and 'mental issues', and finally, a firm resignation from the job after teaching for only two months (September-November 2018).

\section{Courtney's story}

Courtney was born and raised locally. As an EFL learner, Courtney enjoyed English activities such as drama and debate. She thought that her most fruitful English learning period was in Form Four when her English teacher emphasised a solid foundation of grammar, vocabulary and examination skills: ' ... you really need the [English] knowledge in order to go on to more fun stuff' $\left(1^{\text {st }}\right.$ interview).

Courtney was initially unsure whether to be a teacher when she was admitted to a teacher education programme. As the programme progressed, she found her experiences 'joyful' because she had 'more chances to interact with people, like during the two teaching practicums' $\left(1^{\text {st }}\right.$ interview). During her first practicum Courtney adopted a result-oriented approach to push her more capable classes academically; during her second practicum she did her best to motivate her weaker classes and expose them to English. Through her practicum experiences, Courtney cultivated her passion towards teaching.

Courtney was confident about becoming a teacher. She aspired to combine traditional and interactive approaches in her classes to help students lay a solid foundation of English and use the language proactively. She stressed the capacity of teachers to embrace changes in order to better their teaching. She also expected herself to be a facilitator of students' learning. She strived to understand her students' learning needs and to respect individual differences. She therefore found the policy of tailor-making two sets of English textbooks for 
students of different English ability very effective in teaching. Courtney also expected highly of her students. She believed that students should take responsibility for their learning and become autonomous learners.

Courtney was teaching English to junior secondary ESL learners in a local boys' school. She had many extracurricular duties, including running her school's English corner, preparing for the school open day, training students for the Speech Festival and playing a part in the Parent-Teacher Association. Courtney foresaw challenges in managing her workload: 'You are really occupied for teaching and meetings so you can't really imagine how you can spare time for marking assignments and making exam papers' $\left(1^{\text {st }}\right.$ interview). Indeed, after the school year started, Courtney was struggling to cope with her job demands. She led such a busy life that she was spending much less time supporting student learning than she had expected. Time intended for after school remedial lessons was often taken for meetings 'not related to teaching'.

Courtney addressed learner diversity by adopting different teaching strategies in her high-achieving and less capable classes. In her elite classes, she implemented more activities and introduced more advanced concepts; for weaker students, there were more direct instruction and drilling to help them establish a solid English foundation. Despite her good intention, some parents complained about her activity-based approach. 'Some parents called and complained that ... my students are jotting too few things down on their English notebooks. They really want me to have some practical things' ( $2^{\text {nd }}$ interview).

Courtney did not find classroom management a huge problem because the class size was small. She was increasingly confident at managing her classes because she was willing to 'spend time to get to know the personality of each individual student' $\left(2^{\text {nd }}\right.$ interview).

One thing that landed Courtney in isolation and frustration was the lack of collaboration among teachers. For example, regular preparation meetings, intended for exchanging teaching ideas, were used for discussing administrative matters. Her colleagues were not keen to offer Courtney help because of their heavy workload. The help she did manage to obtain from her form coordinators and mentor were mainly on administrative work. This made Courtney aware of 'the importance of self-learning' ( $2^{\text {nd }}$ interview).

Courtney did not attain a satisfactory work-life balance. 'It's sad and frustrating because I don't expect my life to be that busy in my first year' ( $3^{\text {rd }}$ interview). Just as she was struggling whether to continue teaching in that school, she was offered a one-year fulltime postgraduate study opportunity in a local university. After graduation from the MA programme in 2015, she joined another school and has been working there for four years by the time the paper was being revised. Courtney was also interviewed in April 2019 for the first author's new project. As confirmed in the interview, Courtney has been prioritising professional development on her work-life agenda and giving primary attention to teaching innovation and effectiveness over the years: 'I treasure every opportunity to reflect upon what I can do to improve myself'; 'I always remind myself to try something new'. However, in both her schools, she perceives a serious lack of 'sharing culture in materials and pedagogy' and 'collaboration among colleagues'. Another concern is worklife balance, a problem which has become more urgent: 'Now I consider teaching my lifelong career ... I want to start a family and spend more time with my family. I try to find a point of balance. There must be something I need to let go of.' 


\section{Discussion}

The findings presented in the previous section, in the form of biographical accounts of each participant, provide rich content for analysis. Two major themes are discussed in this section.

\section{The changing process of novice teachers' beliefs}

Given the various socio-cultural factors involved in novice teachers' learning environment, we may state that the novice teachers' belief is variable, cumulative and evolutionary, and is subject to the interaction between their individual meaning-making and identity-making, and their embedded learning environment. In line with previous studies on pre-service teachers (Cabaroglu \& Roberts, 2000; Yuan \& Lee, 2014), the novice teachers in the present study experienced four processes related to their beliefs in their teaching work.

The first stage is confirmation, for which the novice teachers strengthened their prior beliefs by perceiving a consistency between these beliefs and the newly presented information. In the case of Stella, the good English foundation laid in senior primary enabled her to perform well in English in secondary school. This further encouraged her to learn English as a major in university, and later choose to be an English teacher. Sally was quite optimistic towards her job because of her good English skills, although she knew that her lack of teaching experience might present challenges in handling parents and students' problems. She believed that teachers are mentors and friends of students and she was willing to establish a friendly relationship with them. In the case of Courtney, her exposure to the many English teaching approaches, including engaging ones like drama and debate and more traditional ones like drilling, has impacted the way she conceptualised English learning and teaching. Her long-held belief that different teaching methods are of value in different contexts was reinforced during her two practicums when she successfully employed different strategies to fulfil her students' learning needs.

The second stage is realisation, which refers to the process that the novice teachers became more fully aware of or picked up a new belief in teaching. Stella experienced trouble coping with the teaching schedule, partly because of discipline problems during lessons, the many extra-curricular activities that she needed to handle, or the extra afterschool tutorials she offered to her less capable students. She realised that she needed more support as a novice teacher. Sally noticed that she was too lenient with the students, and later came to realise the complex and dynamic nature of striking a balance between being a friend and an authority to the students. Courtney realised she needed to try out her activity-based approach, and to explain the rationale to the parents because she thought this was what the students needed.

The third stage is disagreement, which took place when the novice teachers rejected their previously held beliefs. Stella moved from the perception that teacher colleagues should help each other to a new belief that a novice teacher should be self-critical before revealing the problems to her colleagues. In Sally's case, when her efforts were not appreciated by her students and colleagues, her belief was changed: she thought that the students would always take advantage of the teacher's kindness and the teacher should not be so kind to the students. When Courtney lacked collaboration with colleagues, her belief was changed: she thought that self-learning was more important in the workplace. 
The fourth stage is elaboration, for which the novice teachers deepened and expanded their existing beliefs by adding in new dimensions. Stella strengthened her negative beliefs on teaching when she was frustrated because of students' poor learning attitude and a sense of isolation because of her reluctance to share her anxieties with colleagues. Sally further expanded her belief about the powerlessness of being an English teacher when her efforts were not appreciated by her students and colleagues. Courtney further expanded her belief about language teachers through organising more classroom activities. Although she still considered organising teaching activities stressful, she was convinced that different teaching strategies should be adopted to meet students' various needs.

However, the novice teachers did not experience the two final stages of integration and consolidation as identified by Yuan and Lee (2014). Overall, the novice teachers in the present study lacked support in the new community; they failed to refine and reorganise the prior and newly acquired beliefs into a comprehensive and integrated system. Accompanying the process of disagreement, the novice teachers' beliefs were situated to a reversal stage. This was obvious in the case of Sally, who had changed from a more positive and optimistic person to a more negative, pessimistic person at the end of her one-year teaching. She failed to modify and refine her beliefs through her accumulated teaching experiences, but demonstrated a more complex process in which the original beliefs were rejected or replaced by a negative one, and finally, she quitted her job. In the cases of Stella and Courtney, although they still kept their jobs, they experienced a period struggling with whether to stay or leave.

It is challenging to describe novice teachers' belief change processes in a stage-by-stage manner. For example, Sally experienced confirmation, disagreement, realisation, and then elaboration. In the case of Courtney, we can notice that all these four stages came together and concurrently influenced her choice to be a teacher. Although the four stages of confirmation, realisation, disagreement and elaboration are presented above in a linear way with different stages separately described, as newcomers to a professional community, the novice teachers' experience of their belief change was by no means as simple as that. The transformation of belief is an ongoing but non-linear process. For instance, confirmation and realisation can accompany disagreement, and disagreement can lead to reversal. Although the data in the present study could not capture the entire process of novice teachers' cognitive development or routes for their belief change, we need to consider the factor of individual experiences and various encounters in the situated contexts, which may interact with each other and form an individual belief system in every novice teacher.

\section{The impact of changes in novice teachers' beliefs on their identity formation}

It emerges from our data that novice teachers' identity is to a large extent informed by a negotiation between their epistemological beliefs and initial teaching experience. Referring to earlier discussion on Britzman's $(2003,2009)$ three dimensions of voice and Orr's (2012) ideas of isolation, coping, and control, we attempt to understand how our participants' epistemological beliefs and their initial teaching experience contribute to their teacher identity. Overall, the changes in novice teachers' beliefs lead to the changes in their identities. When the novice teachers' beliefs are challenged, their identities are at stake.

Acknowledging the need to make English learning engaging, Stella ventured into the teaching profession with the challenge of exerting her teacher identity in her alma mater. Her lack of confidence, high self-expectation, anxiety and reluctance to seek help made 
her succumb to isolation and a lack of control over her teaching. In terms of the institutional structure, Stella's school was demanding on both teaching and non-teaching duties. Unable to cope with the lack of control, she found her first-year teaching exhausting, with a huge discrepancy between her desired self and actual self. As a result, she considered herself an incompetent teacher who struggled through the year.

Courtney's case shares some similarity with that of Stella. In terms of biography and emotions, Courtney seemed well-prepared for teaching. She was passionate towards teaching. She also recognised the usefulness of a range of pedagogies. The institutional structure was not favourable to her exercise of autonomy. She maintained some autonomy in her teaching, but the heavy workload, limited time to cater for students' needs and ineffective collaboration mechanisms strained her. Again, we observe the obvious presence of isolation and lack of control over her teaching, partly alleviated by her creating spaces for autonomy and exercise of agency such as her attempts at self-learning. This resulted in a strong identity as a passionate teacher.

Sally's case was somewhat different. The institutional structure she was situated in seemed quite invitational to novices in some ways. She found her school and her colleagues supportive initially. Small-class teaching policies were also in place to allow teachers spaces to exercise their agency and autonomy. Coupled with her optimism and clear expectations of herself and her students, everything seemed to point to a bright start in her teaching career. It was the culture within the institutional structure which struck her the most. She felt that her efforts were not appreciated by her colleagues and students. She also perceived a lack of collaboration among colleagues. In a sense, she was isolated emotionally and doubted her ability to teach. Her desired self as a supportive, friendly teacher gradually gave way to a frustrated and pessimistic identity.

Our cases vary, but what is common across them is the way their teacher identity was shaped, which is the result of negotiation between their beliefs and contextual factors. Our participants' beliefs seem to have given way to the prevailing constraints posed by their respective institutional structures, which led to the rise of negative teacher identities. This observation is in line with Orr's (2012) argument that the ability to cope with the demands and lack of control arising from the institutional structure is what sets apart pre-service and established teachers. Overall, as a group of professionals-to-be who go through almost traumatic experiences in confronting their deeply ingrained beliefs of the profession, they negotiate between what they are assigned to be and what they aspire to be.

It is worthwhile to note that all three of our participants had at some point expressed their intention to either quit the school they were working at or leave the profession altogether. This is possibly attributable to the discrepancy between their desired self and the reality. The novice teachers in this study 'made visible their struggles to live out their imagined stories of teaching that attended to who they are, and what they know as they attempted to negotiate their imagined stories within a professional knowledge landscape' (Schaefer \& Clandinin, 2019, p. 63). The resultant negative teacher identity they established might have generated in them a sense of giving up their profession. In particular, when the realities of teaching become apparent to the novice teachers, they may encounter conflict in professional identity construction. Such conflict, or dilemma, or tension shaped their professional identity (Schaefer, 2013), and consequently, a feeling of giving up emerged and became apparent in the novice teachers' stories. In the current study, the three teacher participants negotiated and struggled for their identities of 
'stayers' or 'leavers', largely because of the wavered belief in the value of teaching. More efforts could be devoted to address the issue of novice teachers' attrition.

\section{Conclusion and implications}

By understanding the learning, learning-to-teach and teaching experiences of three firstyear English teachers in Hong Kong, this paper reveals how their teacher beliefs are formed and transformed, and how those beliefs interact with school contexts in shaping their teacher identity. Based on the findings, the following implications can be made.

First, given the struggle our participants experienced during their initial year of teaching, this study highlights the necessity of social-institutional support for novice teachers and a supportive work environment in affording opportunities for their professional development. In light of this, further research is needed regarding how the institutional context may constrain or afford teacher agency and identity, which have a significant impact on novice teachers' 'workplace learning' (Billett, 2001).

Second, the findings suggest that teacher beliefs have a significant impact on the extent to which teachers would exercise their agency to pursue their professional identity. Teachers need a robust professional discourse that they can bring to the situations in which they work. Such professional discourse should empower teachers to draw on their beliefs to gain agency within contexts characterised by systems of accountability and performativity.

Finally, exploration of the three teachers' experiences demonstrates that teachers' personal and professional landscapes may merge and influence their teacher identity construction. In perceiving the lack of connection with fellow teachers, the three novice teachers expressed a need for a supportive and invitational school environment. Therefore, the study points to the necessity of creating a professional space that would allow teachers to talk about their teaching and their personal-professional experiences to enhance collaboration among colleagues. In this regard, schools, policy makers, and teacher educators should take measures to build up social networks in schools to provide novice teachers with opportunities to develop their confidence and competence in the professional community, rather than leaving them to cope by themselves with the work setting norms reserved for more experienced teachers.

\section{Disclosure statement}

No potential conflict of interest was reported by the authors.

\section{Funding}

This work was supported by the The Research Grants Council of the Hong Kong Special Administrative Region, China [GRF / 12403214].

\section{Notes on contributors}

Dr. Jing HUANG is an assistant professor in Department of Education Studies at Hong Kong Baptist University. He was a professor in Zhanjiang Normal University, China before joining HKBU. His 
research is in learner and teacher autonomy, TESOL teacher education and educational ethnography.

Dr. Yi WANG is a language teacher and researcher at Waikato Institute of Technology New Zealand and associate professor at Shandong University of Technology China. Her research interest includes language learner autonomy, teacher cognition, teacheridentity, and teachers' professional development.

Mr. (Mark) Feng TENG is a PhD student in Department of Education Studies at Hong Kong Baptist University. His main research area includes L2 writing, and language teacher education.

\section{ORCID}

Jing Huang (ID) http://orcid.org/0000-0003-1442-9281

Yi Wang (ID http://orcid.org/0000-0003-0052-3699

Feng Teng (D) http://orcid.org/0000-0002-5134-8504

\section{References}

Beauchamp, C., \& Thomas, L. (2009). Understanding teacher identity: An overview of issues in the literature and implications for teacher education. Cambridge Journal of Education, 39, 175-189.

Beijaard, D. (2019). Teacher learning as identity learning: Models, practices, and topics. Teachers and Teaching, 25(1), 1-6.

Billett, S. (2001). Learning through work: Workplace affordances and individual engagement. Journal of Workplace Learning, 13(5), 209-214.

Borg, S. (2011). The impact of in-service teacher education on language teachers' beliefs. System, 39, 370-380.

Britzman, D. (2003). Practice makes practice: A critical study of learning to teach (revised ed.). Albany, NY: State University of New York Press.

Britzman, D. (2009). The very thought of education: Psychoanalysis and the impossible professions. Albany, NY: State University of New York Press.

Brownlee, J. (2004). Teacher education students' epistemological beliefs: Developing a relational model of teaching. Research in Education, 72, 1-17.

Brownlee, J., Edwards, A., Berthelsen, D., \& Boulton-Lewis, G. (2011). Self-authorship in child care student teachers: Is there a link between beliefs and practice? In J. Brownlee, G. Schraw, \& D. Berthelsen (Eds.), Personal epistemology and teacher education (pp. 68-83). New York: Routledge.

Brownlee, J., Syu, J. J., Mascadri, J., Cobb-Moore, C., Walker, S., Johansson, E., ... Ailwood, J. (2012). Teachers' and children's personal epistemologies for moral education: Case studies in early years elementary education. Teaching and Teacher Education, 28, 440-450.

Cabaroglu, N., \& Roberts, J. (2000). Development in student teachers' pre-existing beliefs during a 1-year PGCE programme. System, 28(3), 387-402.

Calderhead, J. (1996). Teachers: Beliefs and knowledge. In D. C. Berliner \& R. C. Calfee (Eds.), Handbook of educational psychology (pp. 709-725). New York: Macmillan.

Chai, C. S., Khine, M. S., \& Teo, T. (2006). Epistemological beliefs on teaching and learning: A survey among pre-service teachers in Singapore. Educational Media International, 43(4), 285-298.

Chan, K.-W. (2003). Hong Kong teacher education students' epistemological beliefs and approaches to learning. Research in Education, 69, 36-50.

Cheng, M., Chan, K.-W., Tang, S., \& Cheng, A. (2009). Pre-service teacher education students' epistemological beliefs and their conceptions of teaching. Teaching and Teacher Education, 25, 319-327.

Creswell, J. W. (2012). Education research: Planning, conducting, and evaluating quantitative and qualitative research (4th ed.). Boston: Pearson Education. 
Feiman-Nemser, S. (2001). From preparation to practice: Designing a continuum to strengthen and sustain teaching. Teachers College Record, 103, 1013-1055.

Harfitt, G. (2015). From attrition to retention: A narrative inquiry of why beginning teachers leave and then rejoin the profession. Asia-Pacific Journal of Teacher Education, 43(1), 22-35.

Hashweh, M. (1996). Effects of science teachers' epistemological beliefs in teaching. Journal of Research in Science Teaching, 33(1), 47-63.

Hollingsworth, S. (1989). Prior beliefs and cognitive change in learning to teach. American Educational Research Journal, 29(2), 325-349.

Holt-Reynolds, D. (1992). Personal history-based beliefs as relevant prior knowledge in course work. American Educational Research Journal, 29(2), 325-349.

Kagan, D. M. (1992). Implications of research on teacher belief. Educational Psychologist, 27, 65-90.

Kang, N. (2008). Learning to teaching science: Personal epistemology, teaching goals, and practices of teaching. Teaching and Teacher Education, 24, 478-498.

Kuhn, D., \& Weinstock, M. (2002). What is epistemological thinking and why does it matter? In B. K. Hofer \& P. R. Pintrich (Eds.), Personal epistemology: The psychology of beliefs about knowledge and knowing (pp. 121-144). Mahwah, NJ: Lawrence Erlbaum Associates.

Merriam, S. B. (2009). Qualitative research: A guide to design and implementation. CA: Jossey-Bass.

Orr, K. (2012). Coping, confidence and alienation: The early experience of trainee teachers in English further education. Journal of Education for Teaching, 38(1), 51-65.

Roth, G., \& Weinstock, M. (2013). Teachers' epistemological beliefs as an antecedent of autonomysupportive teaching. Motivation and Emotion, 37(3), 402-412.

Saunders, J. M., \& Ash, G. E. (2013). Entering the arena: The figured words transitions of preservice teachers. Journal of Adolescent \& Adult Literacy, 56(6), 490-499.

Schaefer, L. (2013). Beginning teacher attrition: A question of identity making and identity shifting. Teachers and Teaching, 19(3), 260-274.

Schaefer, L., \& Clandinin, D. J. (2011). Stories of sustaining: A narrative inquiry into the experiences of two beginning teachers. Learning Landscapes, 4(2), 275-295.

Schaefer, L., \& Clandinin, D. J. (2019). Sustaining teachers' stories to live by: Implications for teacher education. Teachers and Teaching, 25(1), 54-68.

Schaefer, L., Downey, C. A., \& Clandinin, D. J. (2014). Shifting from stories to live by to stories to leave by: Early career teacher attrition. Teacher Education Quarterly, 41(1), 9-27.

Trent, J. (2010). Teacher education as identity construction: Insights from action research. Journal of Education for Teaching, 36(2), 153-168.

Trent, J. (2017). Discourse, agency, and teacher attrition: Exploring stories to leave by amongst former early career English language teachers in Hong Kong. Research Papers in Education, 32(1), 84-105.

Trent, J. (2019). Why some graduating teachers choose not to teach: Teacher attrition and the discourse-practice gap in becoming a teacher. Asia-Pacific Journal of Teacher Education, 47(5), 554-570.

Tsai, -C.-C. (2003). Taiwanese science students' and teachers' perceptions of the laboratory learning environments: Exploring epistemological gaps. International Journal of Science Education, 25(7), 847-860.

Varghese, M., Morgan, B., Johnston, B., \& Johnson, K. (2005). Theorizing language teacher identity: Three perspectives and beyond. Journal of Language, Identity, and Education, 4, 21-44.

Yadav, A., \& Koehler, M. (2007). The role of epistemological beliefs in preservice teachers' interpretation of video cases of early-grade literacy instruction. Journal of Technology and Teacher Education, 15(3), 335-361.

Yuan, R., \& Lee, I. (2014). Pre-service teachers' changing beliefs in the teaching practicum: Three cases in an EFL context. System, 44, 1-12. 